\title{
New insights into therapeutic activity and anticancer properties of curcumin
}

\author{
This article was published in the following Dove Press journal: \\ Journal of Experimental Pharmacology \\ 3I March 2017 \\ Number of times this article has been viewed
}

\section{Abir Kumar Panda \\ Dwaipayan Chakraborty \\ Irene Sarkar \\ Tila Khan \\ Gaurisankar Sa}

Division of Molecular Medicine, Bose Institute, Kolkata, West Bengal, India
Correspondence: Gaurisankar Sa Division of Molecular Medicine, Bose Institute, P-I/I2, CIT Scheme VII M, Kolkata 700054, West Bengal, India Tel +9l 3325693258

Fax +9l 3323553886

Email gauri@jcbose.ac.in
Abstract: Natural compounds obtained from plants are capable of garnering considerable attention from the scientific community, primarily due to their ability to check and prevent the onset and progress of cancer. These natural compounds are primarily used due to their nontoxic nature and the fewer side effects they cause compared to chemotherapeutic drugs. Furthermore, such natural products perform even better when given as an adjuvant along with traditional chemotherapeutic drugs, thereby enhancing the potential of chemotherapeutics and simultaneously reducing their undesired side effects. Curcumin, a naturally occurring polyphenol compound found in the plant Curcuma longa, is used as an Indian spice. It regulates not only the various pathways of the immune system, cell cycle checkpoints, apoptosis, and antioxidant response but also numerous intracellular targets, including pathways and protein molecules controlling tumor progression. Many recent studies conducted by major research groups around the globe suggest the use of curcumin as a chemopreventive adjuvant molecule to maximize and minimize the desired effects and side effects of chemotherapeutic drugs. However, low bioavailability of a curcumin molecule is the primary challenge encountered in adjuvant therapy. This review explores different therapeutic interactions of curcumin along with its targeted pathways and molecules that are involved in the regulation of onset and progression of different types of cancers, cancer treatment, and the strategies to overcome bioavailability issues and new targets of curcumin in the ever-growing field of cancer.

Keywords: apoptosis, cancer, cell signaling, combinatorial therapy, curcumin/nanocurcumin, drug resistance

\section{Introduction}

Cancer causes nearly one-fifth of the deaths worldwide annually. In 2016, an estimated $1,685,210$ cases of cancer were diagnosed in the US alone, and of these 595,690 people died. ${ }^{1}$ In India, every year nearly 1.3 million new cases are reported. In 2013, about 20.1 million cases were diagnosed with cancer globally, ${ }^{2}$ and of these almost 10.2 million or $18.6 \%$ people died. Cancer is a group of diseases driven by the accumulation of successive genetic and epigenetic alterations resulting in apoptosis resistance, uncontrolled cell proliferation, induced metastasis, angiogenesis, and dysfunction of the immune system. ${ }^{3,4}$ Several strategies have been developed in recent years to combat cancer evasion, which includes surgery, hormonal therapy, chemotherapy, and radiation therapy. The type of treatment to be used depends on the location, type, and progression of cancer as well as on the patient's health and preferences. ${ }^{5}$ Chemotherapy is a process in which cancer is treated with one or more cytotoxic antineoplastic drugs (chemotherapeutic agents) as part of a standardized regimen. The term "chemotherapeutic 
agents" includes a variety of drugs that can be divided into broad categories such as alkylating agents and antimetabolites. The efficacy of chemotherapy depends primarily on the stage and type of cancer. ${ }^{6}$

Chemotherapy is one of the major strategies employed to treat cancer, but its effectiveness is largely restricted due to the recurrence of drug resistance. In general, drug resistance to chemotherapeutics is broadly divided into two categories: intrinsic and acquired. In the intrinsic mode, resistancemediating factors preexist in the tumor microenvironment that triggers resistance before chemotherapy is applied to tumor-bearing patients. ${ }^{5}$ On the other hand acquired resistance develops during the treatment of cancers that are mutation-prone and sensitive, caused mainly by mutations during prognosis including environmental stimuli such as over-expression of therapeutic targets or stimulation of cancer-promoting pathway. ${ }^{7}$ Furthermore, recent developments in cancer research increasingly emphasize that tumors contain a high degree of molecular heterogeneity and thus drug resistance can be triggered by a selective group of therapy-induced resistant minor heterogenic subpopulation of cells residing within the tumor mass. ${ }^{7}$

With the advent of modern proteomic, biochemical, and genomic techniques interlinked with bioinformatics, systems biology, and next-generation sequencing approaches, it is now possible to identify genes and their signaling and interatomic networks that are involved in drug resistance and onset of cancer progression. ${ }^{7,8}$ Tumor cells exploit several strategies to hinder the efficacy of drugs such as enhancement of drug efflux, limited uptake of drugs to the cell, alteration, of drug metabolism, mutation of drug targets, activation of cell survival pathway, and blockade of cancer cell apoptosis. ${ }^{5-7}$ In addition to molecular mechanisms, epigenetic alterations and constant shifting of tumor microenvironments are other major drivers of drug resistance. ${ }^{8}$ Recently it has been noticed that the attributes of drug resistance further accelerate in the presence of cancer stem cells (CSCs), which results in deleterious effects against therapeutic approaches. ${ }^{9}$ Molecular and genetic heterogeneities are other primary factors that contribute to drug resistance.

Although the primary goal of chemotherapy is to kill cancer cells from a patient's body, it also affects normal, healthy cells causing severe side effects that in turn results in multiple organ dysfunction. ${ }^{5,8}$ Some of the most common adverse effects of chemotherapy are fatigue, nausea, pain, headache, and infection. Besides cancerous cells, normal hematopoietic cells, epithelial cells, and hair follicles are also affected severely on continuous exposure to chemotherapeutic drugs. ${ }^{8}$ Therefore, chemotherapy - one of the primary and expensive strategies used in the treatment of cancer-often fails in certain conditions due to drug resistance and drug-induced adverse effects, including the death of normal cells. ${ }^{10}$ Hence, recent studies suggest the use of few "adjuvants" in combination with chemotherapy to reduce the adverse effects and drug resistance and to increase the effective targeting of cancerous cells.

Various phytochemicals and cytokines such as nexavar, sutent, rapamycin, interleukin- 2 , IFN- $\alpha / \beta$, curcumin, flavonoids, phytoalexins, phenolic compounds have been used as adjuvants in the chemotherapeutic treatment of cancer. ${ }^{6}$ But phytochemicals compared to cytokines have gained better reception in the field of adjuvant chemotherapy because they are relatively less toxic and cause only fewer side effects. ${ }^{8}$ However, the advantage of using natural phytochemicals and polyphenols is not limited just to its fewer side effects. Phytochemicals are known to affect and modulate multiple diverse biochemical processes and several pathways involved in carcinogenesis. ${ }^{5}$ In addition, they can also act as biological response modifiers supporting immune system function and protect living cells against damage from free radicals., ${ }^{6,8}$ Unlike chemotherapeutic agents, the effects of phytochemicals are not detrimental in nature on other normal living cells; ${ }^{8}$ therefore, reducing physiological and psychological insult of the body that is common in chemotherapy. ${ }^{7}$ Although polyphenols present in fruits and vegetables are widely implicated in cancer prevention, few protective effects of individual compounds such as curcumin have been firmly confirmed in clinical trials based on the differences in dosing, timing, and other confounding factors.

\section{Curcumin and combinatorial therapy in cancer}

Curcumin is a yellow spice derived from the roots (rhizomes) of Curcuma longa commonly known as turmeric. It is a short-stemmed perennial that grows to about $100 \mathrm{~cm}$ in height. C. longa grows naturally throughout the Indian subcontinent and in tropical countries, particularly South East Asia. ${ }^{5}$ As a traditional remedy in "Ayurvedic medicine" and ancient Indian healing system that dates back to 5,000 years, turmeric has been used through the ages as a "herbal aspirin" and "herbal cortisone" to relieve discomfort and inflammation associated with an extraordinary spectrum of infectious and autoimmune diseases. ${ }^{8}$ The yellow-pigmented fraction of $C$. longa contains curcuminoids that are chemically related to its principal ingredient curcumin that was identified as (1E,6E)-1,7-bis (4-hydroxy-3-methoxyphenyl) -1,6- heptadiene-3,5-dione or diferuloylmethane. ${ }^{8}$ 
Curcumin deserves a special mention among the list of adjuvants due to its better success rate in cancer chemotherapy. ${ }^{7}$ Curcumin is nontoxic in nature and has been proposed to increase the therapeutic efficiency of chemotherapeutics as it inhibits $\mathrm{ABC}$ transporter function and increases the oral bioavailability of chemotherapeutics. ${ }^{11}$ Curcumin is being used as an antioxidant since the ancient times. ${ }^{8,12}$ Recently it has been shown that curcumin inhibits tumor growth by inhibiting cell cycle progression or by inducing apoptosis; by inhibiting angiogenesis, the expression of antiapoptotic proteins, multiple cell survival signaling pathways and their cross-communication; and by modulating immune responses. ${ }^{7,13,14}$ Curcumin induces the initiation of both p53-dependent and p53-independent G2/M phase cell cycle arrest, ${ }^{13,15-17}$ thereby restricting cell proliferation and tumor progression. Therefore, curcumin is used either alone or in combination in targeting various types of cancers such as multiple myelomas, pancreatic, lung, breast, oral, prostate, and colorectal cancers, and head and neck squamous cell carcinoma. $^{5}$

\section{Curcumin and its relation with other phytochemicals}

Curcumin has often been used in combination with other phytochemicals such as resveratrol, quercetin, sulforaphane, retinoic acid, and folates in cancer treatment. Resveratrol (trans-3,5,4'-trihydroxystilbene) - a naturally occurring polyphenolic compound found in grapes, berries, peanuts and which is known for its antioxidant, anti-inflammatory, and anticancer properties - is the most successful phytochemical adjuvant used in combination with curcumin. ${ }^{18,19}$ In mice with lung carcinoma, curcumin when administered in combination with resveratrol modulated drug-metabolizing enzymes as well as antioxidant indices and cellular proliferation. ${ }^{20}$ In addition, this combination of compounds has also been shown to reduce prostate cancer indices in mice, ${ }^{21}$ induce apoptosis, inhibit angiogenesis, and reduce the growth of MDA-MB-231 tumor xenografts. ${ }^{22}$ Moreover, this combination has been recently shown to target breast CSCs. ${ }^{23}$ When administered with curcumin, resveratrol has shown efficacy in preventing and treating skin, esophageal, intestinal, and colon tumors in vivo. ${ }^{24}$

Phytochemical quercetin is an important flavanol found in numerous vegetables, fruits, and grains. It occurs in cappers, lovage, and radish leaves. Recently, it has been shown that quercetin when given in combination with curcumin can reduce cell migration, mammosphere formation, and breast cancer mass. ${ }^{25,26}$ Both in vitro and in vivo studies have shown that quercetin can potentiate the efficacy of curcumin and other concomitant drugs by enhancing their bioavailability and accumulation and by sensitizing cancer cells as well. ${ }^{27,28}$

Phytochemical such as retinoic acid, which is derived from vitamin A, has also been used in combination with curcumin to combat cancer. All-trans retinoic acid, when given in combination with curcumin to mice induced with cancer, exerted antiproliferative activity and induced apoptosis in cancer cells by activating one of the three retinoic acid receptors - alpha, beta, and gamma. ${ }^{29}$ Retinoic acid also plays a major role in the regulation of CSCs. ${ }^{30}$

Various research groups have focused on increasing the bioavailability of curcumin by combining other phytochemicals as adjuvants. The most successful among these phytochemicals is piperine, which has been found to increase the absorption of curcumin. ${ }^{27}$ Piperine, an alkaloid found in black pepper, selectively reduces the expression of sulfotransferase and UDP-glucuronosyltransferase in order to facilitate the absorption of curcumin in intestine. ${ }^{31}$ Molecular docking technique has revealed that piperine is capable of intercalating with curcumin forming a hydrogen-bonded complex that facilitates its metabolic transport, thereby increasing its bioavailability. ${ }^{32,33}$ However, recent advances in nanotechnology have provided better options for the delivery and absorption of curcumin. ${ }^{33}$ Another report recently highlighted the fact that curcumin in combination with piperine has been able to target breast CSCs as well.

\section{Curcumin nanoformulation: an efficient therapeutic strategy with improved efficacy}

Although curcumin has long been used extensively to treat several inflammatory diseases including cancer, poor aqueous solubility and reduced bioavailability limit its efficacy as a promising therapeutic agent in cancer therapy. ${ }^{8}$ Curcumin is only slightly soluble in water $(0.0004 \mathrm{mg} / \mathrm{mL}$ at $\mathrm{pH} 7.3)$, which causes immense problems when orally administered. Curcumin is easily hydrolyzed and degraded in neutral and basic solutions but shows greater solubility in acidic environments. Poor absorption, rapid degradation, fast metabolism, and systemic elimination are essential factors that ultimately lead to poor bioavailability. When administered orally, curcumin is poorly absorbed and most of its derivatives such as glucuronide and sulfate conjugates are found majorly in the peripheral and portal circulations. ${ }^{34}$ Furthermore, to be effective in cancer therapy, curcumin should be administered in a high concentration, but patients show intolerance to bulk administration of curcumin. Therefore, poor water solubility, 
use of excessive cosolvents, poor bioavailability, uncontrolled precipitation, and incompatibilities to patients are the most serious problems that restrict curcumin as a novel chemotherapeutic agent in cancer therapy. Hence, an advanced delivery system with increased bioavailability and satisfactory parenteral administration will significantly harness the potential of curcumin as a promising anticancer element in the clinical arena. ${ }^{34}$ Recently, with the advent of nanotechnology, it has become possible to design curcumin-encapsulated nanoparticle or nanocurcumin by compressing its bulky size to less than $100 \mathrm{~nm}$ with superior bioavailability attributes. Several novel strategies have been developed for designing curcumin nanoparticles with enhanced bioavailabilities and targeted drug-delivery systems. In simple approaches, curcumin nanoparticles have been designed with improved bioavailability, devoid of degradation and further metabolism, and with enhanced targeting capacities. ${ }^{35}$

Various types of curcumin nanoparticles appropriate for cancer treatment have been developed, such as polymer nanoparticles, liposomes, micelles, solid lipid nanoparticles (SLNs), and polymer conjugates.

1. Liposomes: Liposomes are closed, spherical, phospholipid vesicles where drugs are incorporated into the aqueous interior. Liposomes have been widely used to enhance the bioavailability and efficacy of curcumin. Recently several modifications of liposomal curcumin with polymeric conjugates have been developed to acquire better clinical outcomes. ${ }^{34}$

2. Polymer nanoparticles: Polymer nanoparticles are small, nano-sized particles that are highly biocompatible and easily circulate in the bloodstream for a longer time. Some of the widely used synthetic polymer conjugates include chitosan, D,L-lactide-co-glycolide (PLGA), poly-ethylene glycol (PEG), poly (n-butyl) cyanoacrylate, silk fibroin, $\mathrm{N}$-iso-propyl acrylamide, and hydrophobically modified starch. PLGAs with carrier stabilizer PEG-5000 were employed to design curcumin-loaded nanoparticles with $97.5 \%$ efficiency and with a particle diameter of $81 \mathrm{~nm} .{ }^{36}$ The PLGA-loaded curcumin nanoparticles showed higher cellular uptake, enhanced bioavailability, and induction of apoptosis in cancer mice models both in vitro and in vivo. ${ }^{36}$

3. SLNs: SLNs are composed of natural lipids such as lecithins or triglycerides that remain solid at normal temperature $\left(37^{\circ} \mathrm{C}\right)$. SLNs can protect labile compounds from chemical degradation and improve bioavailability. ${ }^{35}$ Curcumin-loaded nanoparticles showed enhanced cellular uptake and also proved as promising anticancer agents in breast cancer cells in vitro.

4. Magnetic nanoparticles: Drug-loaded magnetic nanoparticles can be targeted into cancer-infected tissues under the influence of external magnetic fields. Entrapping curcumin in $\mathrm{Fe}_{3} \mathrm{O}_{4}$-curcumin conjugate with oleic acid or chitosan in the outer shell results in the formation of nanosized, fluorescent-magnetic, water dispersible nanoparticles with increased cellular uptake and enhanced bioavailability. ${ }^{36}$

5. Polymer micelles: Polymer micelles are another excellent drug-delivery system extensively used to solve poor solubility, low stability, and poor bioavailability properties of curcumin. Recently curcumin has been encapsulated with in cationic micelles like cetyltrimethyl ammonium bromide or dodecyl trimethyl ammonium bromide for enhancing drug-loading capacity, increasing water solubility, reducing toxicity, and lowering degradation. ${ }^{37}$

6. Microsphere and microcapsules: In such approaches, drugs or curcumin is encapsulated within or dispersed in polymeric particles such as camptothecin, rutin, zedoary oil, and andrographolide to form microspheres or microcapsules that essentially improve efficacy and organ-targeted bioavailability. Microcapsules are been assembled layer by layer and curcumin is be accumulated in hollow microcapsules with polyelectrolyte multilayer shell. ${ }^{37}$ Microcapsule- and microsphere approach-mediated nanoparticle design has shown an increase in the stability and bioactivities of drugs.

7. Microemulsion: Microelumsions are small-droplet dispersions (size 1-100 $\mu \mathrm{M}$ ) of isotropic mixtures of oil and water stabilized by interfacial films of surfactant molecules. Microemulsion systems are ideal for delivery of hydrophobic drugs such as curcumin. As a lipid-based drug-delivery system, microemulsion possesses several advantages such as thermodynamic stability, improved drug dissolution and increased solubility. Triacylglycerol as an oil and Tween-20 as an emulsifier have been used to produce tiny droplets of microemulsion under high-speed and high-pressure homogenization procedures. ${ }^{37}$

8. Inclusion complex: Cyclodextrins are cyclic oligosaccharides composed of six to eight glycosyl monomeric units ( $\alpha-1,4$ linked) with central lipophilic cavities and hydrophilic outer surface layer. Among the three different cyclodextrin molecules $(\alpha, \beta, \gamma), \beta$-cyclodextrins are widely used as they are easily accessible and costeffective, they increase stability, reduce bitterness, enhance water solubility and improve bioavailability. 
$\beta$-Cyclodextrins are conjugated with curcumin to form inclusion complex by solvent evaporation techniques or $\mathrm{pH}$ shift protocols, which show increased uptake of curcumin by cancer cells.

9. Nanogels: Nanogel consists of hydrophilic three-dimensional polymer networks that can uptake large amounts of water or physiological fluid in their interior besides maintaining their internal network structure. Nanogels are one of the efficient drug-delivery procedures due to their high drug-loading capacity, high dispersion stability, targeted drug-delivery efficiency, fast drug-releasing properties, easy chemical modification, and increased drug delivery across the cellular barriers. ${ }^{38}$ Curcumin can be easily encapsulated into the interior of a nanogel, especially for targeted drug delivery.

10. Nanocurcumin: Curcumin nanoparticles can also be made from pure curcumin without using any carrier conjugates. Curcumin can be dissolved with ethanol and homogenized at higher pressure with water containing citric acid $(0.1 \%)$. Curcumin nanoparticles are efficient modes of drug delivery due to their superior bioavailability and increased cellular uptake attributes. ${ }^{38}$

11. Solid dispersions: Solid dispersion involves the dispersion of one or more active ingredients in an inert carrier or matrix at solid state by the process of melting (fusion) solvent. Recently, several strategies such as wet-melting and subsequent freeze-drying have been designed for preparing crystal and amorphous solid dispersions that have proven to improve physicochemical and pharmacokinetic activities of curcumin. ${ }^{38}$

\section{Curcumin as a combinatorial therapy in various cancer types}

None of the known methods of treatment, be it radiation, chemotherapy, or surgery, is $100 \%$ effective in cancer treatment. Therefore, studies highly focus on combinatorial therapies. Curcumin turns out to be the forerunner compound among these adjuvants due to its nontoxic nature and its capacity to prevent the spread of tumor. ${ }^{39}$ Here, we discuss the effects exerted by curcumin in combination with known anticancer drugs in various cancer types.

\section{Curcumin and breast cancer}

Both in the developed and in the developing countries, breast cancer has been identified as the most common type of cancer. Worldwide, over 508,000 women died due to breast cancer as on 2011, and nearly 1.7 million women were diagnosed with this cancer as on $2012 .{ }^{8,40}$ In 2016 , nearly 246,660 cases of breast cancer were registered in the US alone. ${ }^{1}$ A major cause of breast cancer is identified to be mutations in BRCA1 and $B R C A 2$ genes. ${ }^{5}$ A $55-65 \%$ lifetime risk of developing breast cancer is observed in women with a BRCA1 mutation. The risk is $45 \%$ for women with a $B R C A 2$ mutation.

Doxorubicin, an anthracycline antibiotic, is commonly used as a chemotherapeutic agent to treat a wide spectrum of cancers including breast cancer. ${ }^{41}$ Doxorubicin exhibits toxic effects on cancer cells by intercalating with DNA, by disrupting topoisomerase II-mediated DNA damage repair, and by releasing reactive oxygen species leading to oxidative stress and programmed cell death. ${ }^{42}$ However, it suffers from serious limitations of cardiotoxicity and drug resistance. Curcumin in combination with doxorubicin was highly effective in sensitizing cancer cells that are resistant to doxorubicin and in reducing the survival of cancer cells. Curcumin has also been shown to induce the immuno-, hepato-, and cardioprotective properties of doxorubicin. It was reported that doxorubicin triggered an epithelial-to-mesenchymal transition (EMT) in triple-negative breast cancer cells through the activation of TGF $\beta$ and PI3K/AKT pathways. Interestingly, curcumin was found to inhibit these pathways and thus suppress EMT and increase antiproliferative effects (Table 1 and 2). ${ }^{43}$ Meiyanto et al used curcumin and its analogs (PGV-0 and PGV-1) in combination with doxorubicin that enhanced the sensitivity of resistant $\mathrm{MCF}-7$ cells to doxorubicin via increase of sub G-1 cell population and inhibition of NF- $\kappa \mathrm{B}$ activation. ${ }^{44}$ Curcumin is also found to reduce the cytotoxicity of 5-Fluorouracil (5-FU) in human breast cancer cell lines as demonstrated by an increased $\mathrm{LD}^{50}$ value of 5-FU. Administration of dietary curcumin to a human xenograft model in nude mice decreased metastasis of breast cancer to the lung, supported by the suppressed expression of matrix metallopeptidase-9, NF- $\kappa$ B, and cyclooxygenase-2 (COX-2) (Figure 1). ${ }^{45}$ Similarly, treatment of curcumin in combination with paclitaxel in experimental breast cancer nude mice showed pronounced growth inhibitory effect, induced apoptosis, decreased tumor burden, and decreased matrix metalloprotease-9 (MMP-9) expression. ${ }^{46}$ Interestingly, Zhan et al reported that simultaneous treatment of curcumin and paclitaxel inhibited paclitaxel-induced EGFR-signaling in human breast cancer cell lines along with the induction of apoptosis. ${ }^{47} \mathrm{~A}$ preclinical study on breast cancer MCF-7 cells showed that cotreatment of curcumin and tamoxifen synergistically inhibited the survival of tamoxifen-resistant MCF-7 cells, constitutively expressing the activated form of AKT. This study showed that curcumin could sensitize resistant cells and could potentially reverse drug resistance 
(Table 1). ${ }^{48}$ Serasanambati et al observed that $20 \mu \mathrm{M}$ of curcumin enhanced the anticancerous effects of gemcitabine on MCF-7 and MDA-MB-231 breast cancer cells by suppressing gemcitabine-induced NF- $\kappa \mathrm{B}$ activation by $80 \%$, inducing apoptosis, and by decreasing cell proliferation. ${ }^{49}$ Recent studies proved that combined treatment of curcumin and mitomycin- $\mathrm{C}$ sensitized human breast cancer $\mathrm{MCF}-7$ cells to mitomycin $\mathrm{C}$-mediated antiproliferative activity and reduced mitomycin-C-associated adverse effects through the ERK/p38MAPK pathway. ${ }^{50,51}$ Bayet-Robert et al evaluated curcumin in combination with "docetaxel" in advanced and metastatic breast cancer patients in an open-label phase-I dose-escalation trial and came up with promising results to use curcumin as an adjuvant in breast cancer. ${ }^{52}$

\section{Curcumin and colorectal cancer}

Colorectal cancer develops in the colon or rectum. Old age, lifestyle, and genetic causes, in a small percentage of patients, are some of the major factors that cause colorectal cancer. ${ }^{8}$ Colorectal cancer is the third most common type of cancer in the world, comprising of almost $10 \%$ of the reported cases of cancer globally. ${ }^{53}$ Antimetabolites such as capecitabine, 5-FU, floxuridine, and gemcitabine that interfere with the DNA synthesis resulting in the initiation of apoptosis and apoptotic cell death are used in the treatment of colorectal and gastrointestinal cancers. 5-FU is converted into fluorodeoxyuridine monophosphate inside cells that forms a stable complex and irreversibly inhibits thymidylate synthase (TS).This inhibits dTMP production thereby resulting in an imbalance in the ratio of deoxynucleotides and subsequent faulty DNA repair. However, resistance toward 5-FU has been observed in case of increased expression of TS, enhanced activity of deoxyuridine triphosphatase, and overexpression of antiapoptotic proteins (Bcl-2, Bcl-xL, Mcl-1). ${ }^{54}$ But curcumin enhanced 5-FU-induced expression of proapoptotic proteins (caspase-8, -9, -3, PARP, and BAX) and simultaneously it downregulated antiapoptotic (BCL-xL) and proliferative (cyclin D1) proteins leading to cell death (Table 1). Combined treatment of curcumin and 5-FU in chemoresistant colorectal cancer cells mediated apoptosis of resistant cells (Figure 1). ${ }^{55}$ Curcumin-mediated chemosensitization was shown to be effective through the upregulation of miRNA that induced the suppression of EMT in 5-FU-resistant colorectal cancer cells. ${ }^{56}$ Experiments conducted on intestinal tumors in C57BL/6J-Min/+ (Min/+) mice showed that curcumin is capable of regulating lymphocyte-mediated immune function. ${ }^{57}$ Furthermore, after treatment with curcumin, the levels of COX-2 protein expression demonstrates the retardation of adenoma development in mouse intestines..$^{58}$

Gastric cancer, also known as stomach cancer, develops at the lining of the stomach. The most common cause of stomach cancer, which accounts for more than $60 \%$ of cases, is identified as infection by the bacterium Helicobacter pylori..$^{59}$ Globally, stomach cancer is the fifth leading cause of cancer and accounts for $7 \%$ of all cancer cases. It causes $9 \%$ of deaths worldwide and is the third leading cause of death due to cancer. ${ }^{8} 5$-FU or 5 -FU plus oxaliplatin (FOLFOX) are considered standard therapy for stage-II and stage-III gastric cancers. However, this treatment does not eliminate all the cancer cells, thus leading to cancer recurrence. Recently, Patel et al examined the effect of curcumin on FOLFOX chemotherapy to target chemoresistant cells. ${ }^{60}$ They evidence that FOLFOX resistance in gastric and colon cancer cell lines is mediated by marked activation of IGF$1 \mathrm{R}$ and by a moderate increase in EGFRs and v-erb-b2 erythroblasts leukemia viral oncogene homolog 2 (HER-2), $\mathrm{v}$-AKT murine thymoma viral oncogene homolog-1 (AKT), COX-2, and cyclin-D1. Curcumin combination reduced the survival of FOLFOX resistant cells by inhibiting aforementioned genes. ${ }^{60}$ Similar adjuvant approach was adopted for gastric cancer cells, which inhibited the proliferation and induced apoptosis of BGC-823 cells. ${ }^{61}$ In vitro curcumin induced JNK, p38MAPK, and AP-1 transcriptional activities (Table 2). At the same time, curcumin inhibited neurotensin-mediated activator protein-1, NF-kB activation, $\mathrm{Ca} 2+$ mobilization, PGE-2, and EGFR. It downregulated $C O X-1$ and -2, $M M P-2$ and $-9, I L-8$ gene induction, and colon cancer cell migration. ${ }^{8,62}$ Curcumin also significantly reduced benzopyrene-induced stomach papillomas in mice. It has also been reported that curcumin reduces the progression of gastric cancer in rats and inhibits MNNG-induced duodenal tumor in mice. ${ }^{63}$ In rats with colonic tumor, administration of curcumin, sulindac, and PEMC decreased the progression of cancer and also induced apoptosis. ${ }^{63}$ A recent study indicated that cotreatment with curcumin and catechin or curcumin and celecoxib respectively caused significant inhibition of DMH-induced colon carcinogenesis and colorectal cancer in rats. ${ }^{64} \mathrm{Six}$ patients with stomach intestinal metaplasia were included in a phase-I clinical trial and treated with $0.5-12 \mathrm{~g} /$ day of curcumin for 3 months. The results showed that one out of the six patients had histologic improvement in precancerous lesions after treatment. ${ }^{8,59,63}$ These results suggest that adjuvant chemotherapy is recommended with FOLFOX to enhance treatment efficacy, to reduce recurrence, and to prolong survival period. 


\section{Effect of curcumin on leukemia and lymphoma}

Leukemia is a group of cancers that after beginning in the bone marrow causes an abrupt increase in the number of abnormal white blood cells (WBCs) in the blood. These abnormal WBCs, known as blasts or leukemia cells, are not fully developed. Primarily, four types of leukemia are observed - acute lymphoblastic leukemia, acute myeloid leukemia (AML), chronic lymphocytic leukemia (CLL), and chronic myeloid leukemia (CML) - along with some less common types. ${ }^{8}$ In 2012 , nearly 352,000 people were diagnosed with leukemia globally and 265,000 people died. ${ }^{5,8}$ Leukemia is the most common type of cancer in children. However, AML and CLL are most common in adults constituting almost $90 \%$ of all leukemias being diagnosed in adults. Methotrexate (MTX), an antimetabolite and antifolate drug, is being used for the treatment of leukemia. However, MTX therapy is associated with serious toxic effects caused by multiple factors like impaired uptake, enhanced drug efflux, alteration of target enzymes and enhanced cellular pools of folate, thus limiting its use in leukemic cells..$^{65,66}$ Of this, impaired transmembrane uptake is been considered the most frequent cause of resistance to MTX ${ }^{59}$ It has been shown that curcumin increased the uptake of MTX and folic acid in KG-1 cells by upregulating folate receptor $\beta$-mRNA and protein levels. Also, curcumin significantly enhanced the cytotoxic activity of MTX. ${ }^{67}$ Interestingly, a recent study reported that dual drug (curcumin+doxorubicin) loaded in a single nanoparticle formulation inhibited the development of drug resistance by inhibiting the gradual mRNA expression of MDR1 and Bcl-2 in CML blast-like K562 cells and thus prolonged the effect of doxorubicin inside the cells. ${ }^{68}$ Curcumin inhibits cancer growth and apoptosis in T cell leukemia, HTLV-I-transformed T cell leukemia, MT-2, HuT-102, and SLB-1 cell lines, by dose-dependently downregulating JAK and STAT phosphorylation and by inhibiting cyclin D1, cdk1 Cdc25C, and XIAP and survivin expression (Table 2). ${ }^{59,69} \mathrm{It}$ blocks STAT5 activation in CML cells by blocking STAT5 mRNA expression and thereby suppressing the proliferation of WEHI-3b cells. ${ }^{45}$ Curcumin has also been shown to cause telomerase II poisoning in TK-10 and UACC-62 cell lines, thereby causing DNA damage and initiating apoptosis process (Figure 1). ${ }^{70}$ Curcumin when given to acute leukemia cells for 4 hours increases nitric oxide levels and inhibits Th1 cytokines in natural killer cells, thus leading to significant tumoricidal results. ${ }^{6,870}$ Oral administration of curcumin $(50-200 \mathrm{mg} / \mathrm{kg}$ ) in nude mice has been reported to inhibit the development of leukemia (HL-60) cells-induced xenografts as well as lymphoma (SGC7901) cells - induced xenografts. ${ }^{8,62,65}$ Curcumin inhibits the growth of B lymphoma cells both in vitro and in vivo by downregulating AKT activation and tyrosine kinase activity (Table 1). ${ }^{8,71,72}$ Curcumin has also been shown to decrease Wnt 1 gene expression in 35 out of the 70 samples obtained from child leukemia patients. ${ }^{71}$

\section{Curcumin and lung cancer}

Lung cancer is the uncontrolled growth of abnormal cells that begins in one or both lungs, usually in the cells that line the air passages. The two primary types of lung cancer are small cell lung carcinoma and non-small-cell lung carcinoma (NSCLC). ${ }^{59}$ Lung cancer is considered to be the most common cause of death due to cancer in men, and in case of women, it stands next to breast cancer. Globally, 1.8 million people were diagnosed with lung cancer in 2012 and 1.6 million people died. ${ }^{8}$

Treatment includes surgery, radiotherapy, and chemotherapy with drugs such as carboplatin, doxorubicin, gemcitabine, paclitaxel, vinorelbine, topotecan, and irinotecan. However, doxorubicin often faces the limitation of lesser uptake. To improve the stability and to codeliver doxorubicin slowly into the system, Wang et al developed methoxy poly(ethylene glycol)-poly( $\varepsilon$-caprolactone) (MPEG-PCL) micelles loaded with curcumin and doxorubicin (Cur-Dox/ MPEG-PCL), which improved antitumor responses in lung cancer model. ${ }^{73}$ Human xenograft model in nude mice when subjected to dietary curcumin treatment showed decreased metastasis of breast cancer to the lung due to a reduction in the expression of NF-KB, MMP-9, and COX (Table 1). ${ }^{5,7,8}$ Curcumin has been shown to downregulate NAT activity and STAT1 activation (Table 2), thereby inhibiting cancer growth and inducing apoptosis in H1299 and A549 cells (Figure 1). ${ }^{74}$ Use of curcumin as an adjuvant in chemotherapy is further affirmed by the fact that it not only reduces the invasive properties of CL1-5 cells but also inhibits the proliferative properties of NCI-H460 and -H520 cells. ${ }^{8,62,74}$

Cisplatin or carboplatin when used in the treatment of NSCLC often give rise to cisplatin-resistant lung cancer cells (A549) that acquire EMT phenotype and invasiveness. Curcumin augmented the cell proliferation inhibitory activity and promoted the apoptotic activity of cisplatin (DDP) in DDP-resistant lung adenocarcinoma cells. ${ }^{7,8,63}$ Baharuddin et al studied the effect of curcumin on double-positive (CD166+/EpCAM+) cell subpopulation in NSCLC cell lines (A549 and H2170), and they found that curcumin sensitized those cell population to cisplatin treatment by downregulating cyclin D1 and activating p21/Apaf/caspase-9 pathway. 
Therefore, double-positive cell subpopulation when treated with a combination of curcumin and cisplatin induced cell cycle arrest resulting in the initiation of the intrinsic apoptotic pathway. ${ }^{75}$ These results have led clinicians to consider curcumin as an adjuvant in chemotherapeutic approaches.

\section{Curcumin and cervical cancer}

Uterine cancer is an uncontrolled malignant growth of cells in uterine tissues. Uterine cancer can be of various types depending upon the site of its origin in the uterus. Cervical cancer is the most frequent among them and is considered the second most common cancer among the women of the developing world. ${ }^{5,7}$ In more than $90 \%$ of cases, uterine cancer is caused by human papillomavirus (HPV), while other factors such as smoking and birth control pills are also considered risk factors. Globally, 528,000 cases of cervical cancer were reported in 2012 with 266,000 deaths. ${ }^{4,6,8}$ This makes cervical cancer the fourth most common cancer and the fourth most common cause of death due to cancer in women. ${ }^{6,8,39}$ Treatment most commonly involves a combination of chemotherapeutic drugs such as hycamtin, cisplatin, and paclitaxel.

Taxol is the drug of choice for breast, cervical, and epithelial ovarian cancers. However, the success of paclitaxel therapy is limited due to associated neuro- and myelotoxicities and development of drug resistance. ${ }^{76}$ Bava et $\mathrm{al}^{77}$ investigated the synergistic pathways of curcumin and paclitaxel and reported that curcumin downregulated taxol-induced NF- $\kappa$ B activation and phosphorylation of serine/threonine kinase AKT in cervical cancer cells (Table 1). ${ }^{59}$ However, it was found that even though curcumin reduces the harmful side effects of taxol, it did not inhibit taxol-induced tubulin polymerization and cyclin-dependent kinase Cdc2 activation in cervical cancer. ${ }^{77}$ The study also hinted at the possibility of involvement of other pathways induced by paclitaxel that may lead to the activation of NF- $\kappa \mathrm{B}$ (otherwise downregulated by curcumin). It showed the upregulation of paclitaxel-induced survivin by AKT, inde-

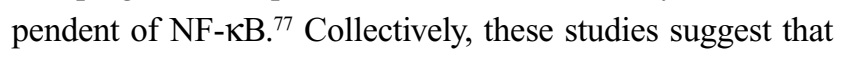
curcumin acts as a potent chemosensitizer to paclitaxel therapy.

Cisplatin has been widely used in the treatment of testicular, ovarian, bladder, colorectal, and cervical cancers. However, cisplatin chemotherapy is disappointing in cervical cancer due to the development of drug resistance. Also, EMT was found to play an important role in cisplatin-resistant ovarian cancers in human patients as is evident from the upregulation of EMT transcription factors slug, snail, twist2, zeb2, and mesenchymal marker vimentin. ${ }^{78}$ One of the few studies that focused on the effect of curcumin in uterine cancers has shown that curcumin is capable of downregulating Ets-1 and BCL-2 (Table 2) expression and as a result it can induce apoptosis against endometrial cancer cell line (Figure 1). ${ }^{8,63}$ The sensitivity of vinblastine, etoposide, and mitoxantrone was found to increase in drug-resistant human cervical cell lines when they came in contact with THC, a major metabolite of curcumin. ${ }^{7,8,63}$ In a phase-I clinical study, one out of four patients with uterine cervical intra-epithelial neoplasms showed histological improvements when they were treated with a daily $0.5-12 \mathrm{~g}$ dose of curcumin for 3 months. ${ }^{7,8,63,66}$

\section{Curcumin and oral cancer}

Oral cancer or mouth cancer falls under the group of head and neck cancer and is defined as any malignant cell growth in the oral cavity. Globally, in 2013, 135,000 people died of oral cancer. ${ }^{1}$ Oral cancer represents only $2-4 \%$ of cancers diagnosed every year in the US. ${ }^{1,8,39}$ Strong risk factors for oral cancer include chewing betel. In India where such practice is common, oral cancer represents up to $40 \%$ of all cancers, which is in stark contrast with US and UK where the maximum rate of oral cancer is $4 \% .^{5,8}$

Studies have shown that curcumin synergistically acts with epigallocatechin-3-gallate, which is a G2 phase blocker and results in growth inhibition in in vitro oral cancer cell lines. ${ }^{8,63,79}$ It has also been shown that treatment with curcumin not only increases the expression and function of cytochrome P450 (CYP) 1A1 and CYP1B1 in (Table 2) SCC-25 but also causes hindrance in growth and DNA synthesis in oral cancer cell line SCC-25 (Figure 1). ${ }^{5,79,80}$ A recent study demonstrated that curcumin when given to SCC-25 was able to inhibit tobacco-induced NF-kB activation and COX-2 expression, thus resulting in the apoptosis of malignant cells (Table 1).${ }^{59,80}$ An in vitro experiment on SCC-25 cells showed that curcumin has radiotherapy sensitizing effects on oral cancer cells. ${ }^{59,80} \mathrm{~A}$ phase-I clinical trial conducted in oral cancer patients using curcumin at a dose of 0.5-12 g/day for 3 months showed histological improvements in precancerous lesions in $29 \%$ of patients. ${ }^{8,59,63}$ Besides this, an early clinical study described a decrease in pain, exudates, itching, and lesion size upon application of curcumin ointment in oral cancer patients. $5,8,63$

\section{Curcumin and novel treatment in CSC sensitization}

Over the past decade, there has been a growing body of evidence supporting the concept that tumor is driven by a minor subpopulation of self-renewing CSCs. It was first identified in the hematopoietic system and subsequently in a variety of solid tumors including the brain, breast, colon, prostate, and others. ${ }^{81}$ Till now, the traditional methods of treatment have been overlooking this issue, and the drug targets are mainly the non-CSC 
Table I Different pathways of various cancers regulated by curcumin as an adjuvant

\begin{tabular}{|c|c|c|c|c|c|}
\hline \multirow{2}{*}{$\begin{array}{l}\text { Serial } \\
\text { no. }\end{array}$} & \multirow{2}{*}{$\begin{array}{l}\text { Types of } \\
\text { cancer }\end{array}$} & \multicolumn{2}{|c|}{ Pathways affected by curcumin } & \multirow{2}{*}{$\begin{array}{l}\text { Drugs normally given } \\
\text { in combination }\end{array}$} & \multirow[t]{2}{*}{ References } \\
\hline & & Upregulated & Downregulated & & \\
\hline I. & Breast cancer & $\begin{array}{l}\text { p53-dependent BAX pathway, } \\
\text { mitotic spindle disruption }\end{array}$ & $\begin{array}{l}\text { LOX pathway, MMP-9 pathway, } \\
\text { and metastasis }\end{array}$ & $\begin{array}{l}\text { Doxorubicin, brentuximab, } \\
\text { carboplatin, vinblastine }\end{array}$ & $8,59,63,89-95$ \\
\hline 2. & Lung cancer & $\begin{array}{l}\text { P21/Apaf/caspase } 9 \text { pathway of } \\
\text { apoptosis }\end{array}$ & $\begin{array}{l}\text { STATI, NAT pathway, and } \\
\text { FPTase-mediated cell growth }\end{array}$ & $\begin{array}{l}\text { Gemcitabine, topotecan, } \\
\text { pertuzumab }\end{array}$ & $8,59,63,74,95-99$ \\
\hline 3. & Colorectal cancer & $\begin{array}{l}\text { JNK, p38MAPK pathway, } \\
\text { TRAIL-induced apoptosis }\end{array}$ & $\begin{array}{l}\text { Notch I pathway, } \\
\text { COX-2-mediated cell renewal }\end{array}$ & 5-Fluorouracil, trastuzumab & $8,59,62,63,99-105$ \\
\hline 4. & Leukemia & $\begin{array}{l}\text { Caspase-3 and -8, P27 KIP-I } \\
\text { pathway }\end{array}$ & $\begin{array}{l}\text { Cyclin D and NF-KB-mediated cell } \\
\text { division }\end{array}$ & Methotrexate, bosutinib & $\begin{array}{l}8,59,63,106-110 \\
111\end{array}$ \\
\hline 5. & Prostate cancer & $\begin{array}{l}\text { BIM-mediated apoptosis, BAX } \\
\text { pathway }\end{array}$ & $\begin{array}{l}\text { NF- } \kappa B \text {-induced growth, AKT } \\
\text { pathway, and cell division }\end{array}$ & Vinorelbine, cobimetinib & $\begin{array}{l}8,59,62,112-117 \\
118\end{array}$ \\
\hline 6. & $\begin{array}{l}\text { Cervical and } \\
\text { uterine cancers }\end{array}$ & BAD-mediated apoptosis & $\begin{array}{l}\text { ETS-I production, NF- } K B \text {, and } \\
\text { AP-I pathways }\end{array}$ & Cisplatin, carboplatin & $8,59,62,119-123$ \\
\hline 7. & Oral cancer & P450 pathway and apoptosis & COX-2 pathway and cell renewal & Radiation, faslodex & $8,59,62,80,124,125$ \\
\hline 8. & Lymphoma & BAX and BIM pathways & $\begin{array}{l}\text { JAK-STAT, tyrosine kinase, and } \\
\text { AKT pathways }\end{array}$ & Doxorubicin, methotrexate & $\begin{array}{l}8,59,62,113 \\
|26-| 28,|1|\end{array}$ \\
\hline
\end{tabular}

Abbreviations: COX, cyclooxygenase; MMP, matrix metalloprotease; LOX, lipoxygenase; TRAIL, TNF-related apoptosis-inducing ligand; NAT, arylamine N-acetyltransferase; NF-KB, nuclear factor-kappa B; AP-I, activating protein I; STAT, signal transducers and activators of transcription; FPTase, farnesyl protein transferase; JAK, janus kinase; JNK, c-jun N-terminal kinase; MAPK, mitogen-activated protein kinase.

Table 2 Different pathways of various cancers regulated by curcumin alone

\begin{tabular}{|c|c|c|}
\hline Types of cancers & Signaling pathways effected & References \\
\hline Breast cancer & Upregulation of $\mathrm{p} 53$ and $\mathrm{BAX}$, cyclin $\mathrm{DI}$, and mitochondrial release of cytochrome $\mathrm{c}$ & $5,8,129$ \\
\hline Lymphoma & $\begin{array}{l}\text { Inhibits both NF-KB and STAT3 activation, thereby inhibiting BCL-2, BCL-xL, cFLIP, XIAP, c-IAPI, } \\
\text { survivin, c-MYC, and cyclin DI }\end{array}$ & $5,8,|30| 3 \mid$, \\
\hline Prostate cancer & Upregulation of the expression of TRAIL-RI/DR4, TRAILR2/DR5, BAX, BAK, p2I/WAFI, and p27/KIP-I & $5,8,132$ \\
\hline \multirow[t]{2}{*}{ Cervical cancer } & Upregulation of proapoptotic BAX, AIF, release of cytochrome c, and caspase- 3 and -9 activities & $5,8,133$ \\
\hline & Downregulation of antiapoptotic BCL-2, BCL-xL & \\
\hline Leukemia & Inhibition of serine/threonine protein kinase and AKT pathway & $5,8,111$ \\
\hline Lung cancer & Activation of caspase- 3 and caspase- 9 & $5,8,134$ \\
\hline Colorectal cancer & Downregulation of COX-2 and inhibition of PGE2 synthesis & 5,105 \\
\hline
\end{tabular}

cancer cells. ${ }^{81,82}$ The CSCs that are capable of surviving despite treatment by chemotherapy and radiation often lead to a recurrence of cancer in the treated patients. Therefore, development of therapeutic strategies that specifically target CSCs has long been an important goal in research, as that might ensure the to prevention of relapse of cancer in the treated patients.

However, recent studies in the field of cancer have shown that various adjuvants when given with traditional chemotherapeutic agents might target CSCs along with other cancer cells. Curcumin has still now been proved to be the most efficient of these adjuvants, which when given in combination with dasatinib was capable of inhibiting cellular growth, invasion, and colonosphere formation and also capable of reducing CSC population as proven by the decreased expression of CSC-specific markers. ${ }^{81,83}$ Curcumin also inhibited signal transducer and activator of transcription-3 (STAT3) phosphorylation, cell viability, and tumor sphere formation in colon CSCs. ${ }^{6,8,81}$ Another report recently highlighted the fact that curcumin in combination with piperine also was able to target breast CSCs. ${ }^{84}$
Like normal stem cells, CSCs may utilize many of the same signaling pathways including Wnt, Notch, and Hedgehog pathways. Curcumin is capable of exerting a variety of anticarcinogenic effects both in vivo and in vitro and, therefore, can inhibit many signaling pathways that can alter the stemness of a cell. Emerging evidence from around the globe suggests that curcumin can exert its anticarcinogenic effects by targeting CSCs by disrupting stem cell signaling pathways. ${ }^{85}$

The molecular mechanisms through which curcumin can exert its effect on the CSCs are as follows: 1) signaling pathways, including Wnt/ $\beta$-catenin, Sonic Hedgehog, Notch, and PI3K/AKT/mTOR, and 2) EMT at multiple levels. These facts emphasize that curcumin can act as a chemosensitizer which makes CSCs now sensitive toward anticancer therapy. Therefore, treatment with a combination of an anticancer agent along with curcumin could be much more effective than that with anti-cancer agent alone. ${ }^{86}$ This potential treatment modality using curcumin as an adjuvant can be further developed by utilizing more effective drug-delivery system like nano molecules, which can open a new avenue to prevent cancer and its relapse. 


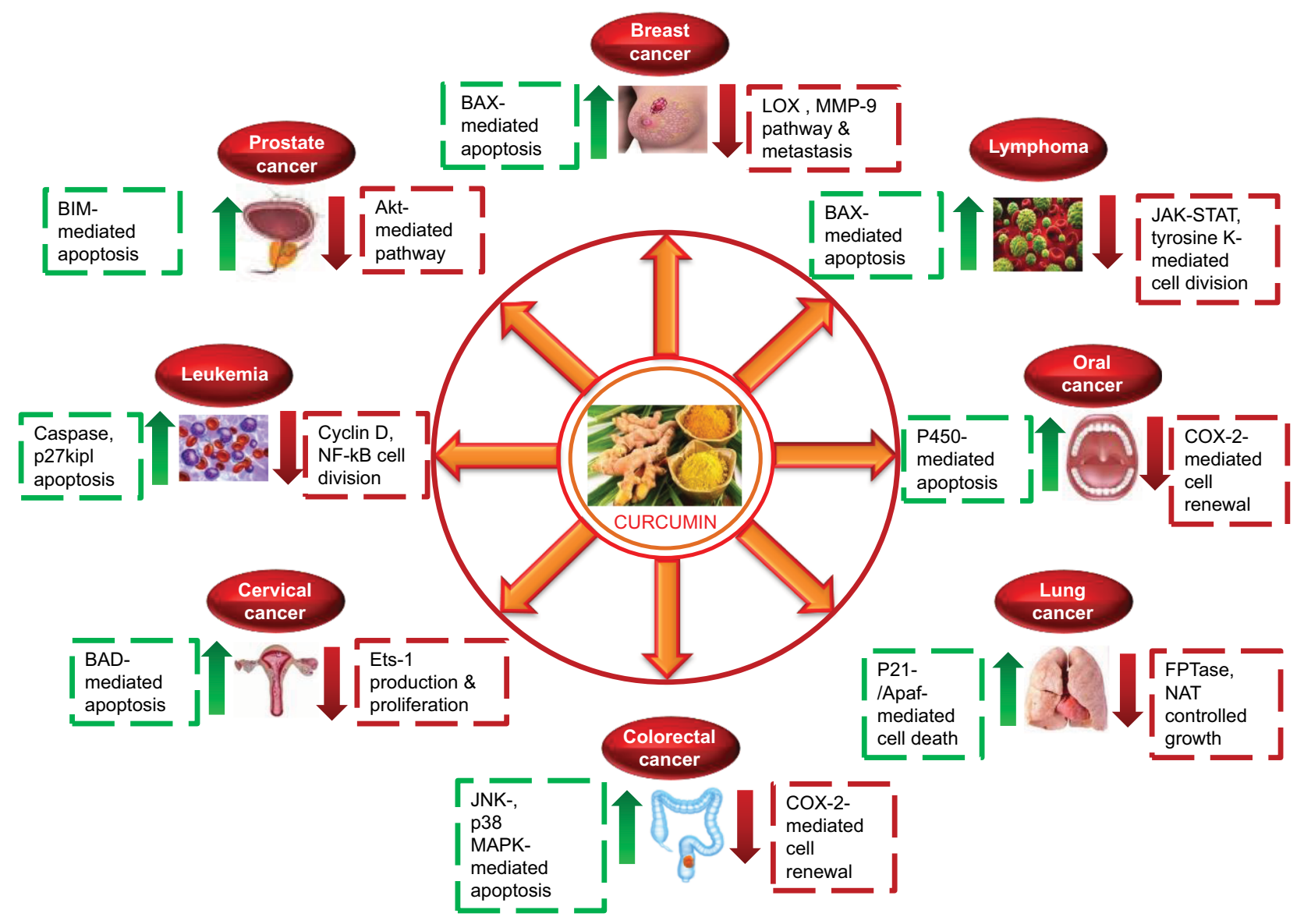

Figure I Effect of curcumin on various cellular pathways of different types of cancer. Abbreviations: MMP, matrix metalloproteinase; COX, cyclooxygenase.

\section{Curcumin in clinical trials and human treatment}

Clinical trials using curcumin and its combination against cancer are still in their infancy. However, in response to the recent in vitro and in vivo studies conducted in various research laboratories worldwide, chemopreventive and other therapeutic effects of curcumin, a number of clinical trials have been approved that target the pharmacokinetics, safety, and efficacy of curcumin in different types of cancer. Other new methods and combination of curcumin treatment are currently ongoing across the world. The first clinical trial of curcumin as an anticancerous molecule was conducted in 1987 by Kuttan et al in patients with external cancerous lesions. ${ }^{17}$ Since then curcumin has been used alone or in combination in some clinical trials. Some of these clinical trials where curcumin has been used to treat cancer patients have reported certain encouraging and successful results. The most successful results were found in patients with pancreatic cancer, external cancer lesions, and postsurgery inflammation. ${ }^{87}$ Recent clinical trials have also reported antitumor activities in neoplastic diseases such as colon cancer, myeloma, and gastric cancer. Current trials focus on ovarian, breast, lung, and oral cancers. Some of the recent, completed, and ongoing clinical trials of curcumin in the treatment of different types of cancer are summarized in Table $3 .{ }^{88}$

\section{Curcumin in therapy: challenges and future scope}

Being a nontoxic, highly antioxidant, and anti-inflammatory agent, curcumin has been demonstrated to possess multifaceted therapeutic and pharmacologic effects. These effects of curcumin have not only consolidated its use as a preventive and therapeutic agent against cancer but also have paved way for its use as an anti-inflammatory agent to combat reactive oxygen species and inflammation in the human body. ${ }^{8}$ The targets of curcumin include an array of molecules such as enzymes, cytokines, growth factors and their receptors, and even proteins that act as regulators of apoptosis and cell proliferation. ${ }^{39}$ Though numerous studies across the world have validated the role of curcumin in different animals, further human studies are needed to confirm these validations.

The process of drug development is extremely expensive, filled with hurdles, and also includes a wide chance for failure. Developing a curcumin-based drug is not easy either and the task of drug development becomes more challeng- 
Table 3 Recent clinical trials using curcumin as an anticancer agent

\begin{tabular}{|c|c|c|c|c|c|c|}
\hline $\begin{array}{l}\text { Serial } \\
\text { no. }\end{array}$ & Cancer type & $\begin{array}{l}\text { Trial } \\
\text { condition }\end{array}$ & Trial & Location & $\begin{array}{l}\text { Identifier } \\
\text { no./ref* }\end{array}$ & $\begin{array}{l}\text { Last } \\
\text { updated }\end{array}$ \\
\hline I. & Breast cancer & Completed & $\begin{array}{l}\text { Curcumin for the prevention of } \\
\text { radiation-induced dermatitis in } \\
\text { breast cancer patients }\end{array}$ & University of Rochester & NCT0I042938 & 2013 \\
\hline 2. & Cervical cancer & Completed & $\begin{array}{l}\text { Effect of curcumin addition to standard } \\
\text { treatment on tumur-induced } \\
\text { inflammation in endometrial carcinoma }\end{array}$ & $\begin{array}{l}\text { University Hospital, } \\
\text { Gasthuisberg }\end{array}$ & NCT020I7353 & 2016 \\
\hline 3. & Pancreatic cancer & Completed & $\begin{array}{l}\text { Trial of curcumin in advanced } \\
\text { pancreatic cancer }\end{array}$ & $\begin{array}{l}\text { M.D. Anderson Cancer } \\
\text { center }\end{array}$ & NCT00094445 & 2014 \\
\hline 4. & $\begin{array}{l}\text { Head and neck } \\
\text { cancer (including } \\
\text { oral cancer) }\end{array}$ & Completed & $\begin{array}{l}\text { Curcumin biomarker trial in head } \\
\text { and neck cancer }\end{array}$ & $\begin{array}{l}\text { Louisiana State University } \\
\text { Health Sciences Center }\end{array}$ & NCT0II 60302 & 2016 \\
\hline 5. & Colon cancer & Completed & $\begin{array}{l}\text { Curcumin for the prevention of colon } \\
\text { cancer }\end{array}$ & $\begin{array}{l}\text { University of Michigan } \\
\text { Cancer Center }\end{array}$ & NCT00027495 & 2013 \\
\hline 6. & Prostate cancer & Completed & $\begin{array}{l}\text { Radiosensitizing and radioprotective } \\
\text { effects of curcumin in prostate cancer }\end{array}$ & $\begin{array}{l}\text { Shahid Beheshti University } \\
\text { of Medical Sciences }\end{array}$ & NCT0I9I7890 & 2016 \\
\hline 7. & Breast cancer & Completed & $\begin{array}{l}\text { Prophylactic topical agents in patients } \\
\text { with non-inflammatory breast cancer } \\
\text { or breast cancer in situ (Curcumin-II) }\end{array}$ & $\begin{array}{l}\text { National Cancer Institute } \\
(\mathrm{NCl})\end{array}$ & NCT02556632 & 2016 \\
\hline 8. & Gastric cancer & Ongoing & $\begin{array}{l}\text { Curcumin in preventing gastric } \\
\text { cancer in patients }\end{array}$ & $\begin{array}{l}\text { National Cancer Institute } \\
(\mathrm{NCl})\end{array}$ & NCT02782949 & 2016 \\
\hline 9. & Colon cancer & Ongoing & $\begin{array}{l}\text { Curcumin in combination with 5-FU } \\
\text { for colon cancer }\end{array}$ & Baylor Research Institute & NCT02724202 & 2016 \\
\hline 10. & Cervical cancer & Ongoing & $\begin{array}{l}\text { Topical curcumin for precancer } \\
\text { cervical lesions }\end{array}$ & Emory University & NCT02944578 & 2016 \\
\hline 11. & Lymphoma & Ongoing & $\begin{array}{l}\text { Curcumin and cholecalciferol in treating } \\
\text { patients with chronic lymphocytic } \\
\text { leukemia or small lymphocytic } \\
\text { lymphoma }\end{array}$ & $\begin{array}{l}\text { National Cancer Institute } \\
(\mathrm{NCl})\end{array}$ & NCT02100423 & 2016 \\
\hline 12. & Breast cancer & Ongoing & $\begin{array}{l}\text { Docetaxel with or without curcumin } \\
\text { in treating patients with breast cancer }\end{array}$ & Centre Jean Perrin & NCT00852332 & 2016 \\
\hline 13. & Lung cancer & Ongoing & $\begin{array}{l}\text { Cohort trial of curcumin plus tyrosine } \\
\text { kinase inhibitors (TKIs) for EGFR-mutant } \\
\text { advanced NSCLC }\end{array}$ & Lady Davis Institute & NCT0232I293 & 2016 \\
\hline 14. & Breast cancer & Ongoing & $\begin{array}{l}\text { Phase-Il study of curcumin vs placebo } \\
\text { for chemotherapy-treated breast cancer } \\
\text { patients undergoing radiotherapy }\end{array}$ & Emory University & NCT0I740323 & 2016 \\
\hline
\end{tabular}

Note: *www.clinicaltrials.gov.

Abbreviations: 5-FU, 5-fluorouracil; NSCLC, non-small-cell lung carcinoma.

ing due to its poor absorption and low bioavailability rates. ${ }^{7}$ Though studies regarding the process of drug development in curcumin are still in early stages, many clinical trials are currently focusing on using curcumin as an adjuvant or as a therapeutic agent in the prevention and in the treatment of cancer. ${ }^{87}$ These clinical trials and abundant studies conducted worldwide not only indicate the tremendous potential of curcumin regarding cancer therapy but also show the picture of a near future where curcumin can be a key weapon in the never-ending war against cancer.

\section{Conclusion}

Cancer still remains undefeated in the history of mankind with an annual death rate of over a million globally. Thus, new methods of combating the disease are emerging from the various research work being done all over the world. Curcumin is a boon in the phase of new discovery as it specifically targets cancer cells and is nontoxic to other body cells. As we have seen in this review, curcumin acting as an adjuvant with other chemotherapeutic drugs is capable of not only preventing the relapse of cancer but also decreasing tumor mass and cancer progression. ${ }^{5,6}$ However, in this success story of curcumin, there also lies the fact that the bioavailability of curcumin is very less. To combat this problem, new approaches are being formulated such as production of nanocurcumin. There have also been cases where curcumin is seen to affect the immune system, thereby decreasing the tolerance to cancer, but the exact molecular mechanisms of such processes are yet to be explored. ${ }^{8}$ Curcumin has been also shown to effect microRNAs and other epigenetic modifiers of 
the cell thereby reducing the progression of cancer, although the intricate regulation by curcumin on epigenetic modifiers is still not elucidated. The discovery of better ways of increasing bioavailability of curcumin and the pathways by which it alters the epigenetic modifiers and immune system ${ }^{39}$ will not only increase our knowledge but also provide better insights as to how curcumin can be used as an adjuvant. Thus, the future prospect of research on curcumin is going to be a very exciting field of research for the coming decades and will provide us with better mechanisms of utilizing curcumin as an adjuvant and maybe as a mainstream drug against cancer in the near future..$^{59,81}$

\section{Acknowledgments}

Authors are thankful to Sreeparna Chakraborty of Bose Institute for editorial assistance of the manuscript. This work was supported by research grants from the Department of Science and Technology, Government of India.

\section{Author contributions}

All authors contributed toward data analysis, drafting and critically revising the paper and agree to be accountable for all aspects of the work.

\section{Disclosure}

The author reports no conflicts of interest in this work.

\section{References}

1. National Cancer Institute [database on the Internet]. Bethesda, MD: Cancer Statistics. Available from: https://www.cancer.gov/aboutcancer/understanding/statistics. Accessed April 3, 2016.

2. Howlader N, Noone AM, Krapcho M, et al. SEER Cancer Statistics Review, 1975-2013, Bethesda, MD: National Cancer Institute. Available from: http://seer.cancer.gov/csr/1975_2013/, based on November 2015 SEER data submission.

3. Hanahan D, Weinberg RA. The hallmarks of cancer. Cell. 2000;100(1): $57-70$.

4. Nakano K, Vousden KH. PUMA, a novel proapoptotic gene, is induced by p53. Mol Cell. 2001:7(3);683-694.

5. Das T, Sa G, Saha B, Das K. Multifocal signal modulation therapy of cancer: ancient weapon, modern targets. Mol Cell Biochem. 2010; 336(1-2):85-95.

6. Bose S, Panda AK, Mukherjee S, Sa G. Curcumin and tumor immuneediting: resurrecting the immune system. Cell Div. 2015;10:6.

7. Sa G, Das T. Anti-cancer effects of curcumin: cycle of life and death. Cell Div. 2008;3:14.

8. Chakraborty S, Sarkar T, Roy D, Bhattacharya A, Chakraborty D, Sa G. Multi-edged sword against cancer: ancient exotic spice. Indian J Physiol Allied Sci. 2014;68(4):129-150.

9. Hossain DM, Bhattacharyya S, Das T, Sa G. Curcumin: the multi-targeted therapy for cancer regression. Front Biosci (Schol Ed). 2012;4:335-355.

10. Aggarwal BB. Nuclear factor-kappaB: the enemy within. Cancer Cell. 2004;6(3):203-208.

11. Shukla S, Robey RW, Bates SE, Ambudkar SV. Sunitinib (Sutent, SU11248), a small-molecule receptor tyrosine kinase inhibitor, blocks function of the ATP-binding cassette (ABC) transporters P-glycoprotein (ABCB1) and ABCG2. Drug Metab Dispos. 2009;37(2):359-365.
12. Campbell FC, Collett GP. Chemopreventive properties of curcumin. Future Oncol. 2005;1(3):405-414.

13. Choudhuri T, Pal S, Das T, Sa G. Curcumin selectively induces apoptosis in deregulated cyclin D1-expressed cells at G2 phase of cell cycle in a p53-dependent manner. J Biol Chem. 2005;280(20): 20059-20068.

14. Bhattacharyya S, Mandal D, Sen GS, et al. Tumor-induced oxidative stress perturbs nuclear factor-kappaB activity-augmenting tumor necrosis factor-alpha-mediated T-cell death: protection by curcumin. Cancer Res. 2007;67(1):362-370.

15. Moos PJ, Edes K, Mullally JE, Fitzpatrick FA. Curcumin impairs tumor suppressor p53 function in colon cancer cells. Carcinogenesis. 2004;25(9):1611-1617.

16. Jee SH, Shen SC, Tseng CR, Chiu HC, Kuo ML. Curcumin induces a p53-dependent apoptosis in human basal cell carcinoma cells. J Invest Dermatol. 1998;111(4):656-661.

17. Kuttan R, Sudheeran PC, Josph CD. Turmeric and curcumin as topical agents in cancer therapy. Tumori. 1987;73(1):29-31.

18. Sinha D, Biswas J, Sung B, Aggarwal BB, Bishayee A. Chemopreventive and chemotherapeutic potential of curcumin in breast cancer. Curr Drug Targets. 2012;13(14):1799-1819.

19. Bishayee A. Cancer prevention and treatment with resveratrol: from rodent studies to clinical trials. Cancer Prev Res (Phila). 2009;2(5):409-418.

20. Liu Y, Wu YM, Yu Y, et al. Curcumin and resveratrol in combination modulate drug-metabolizing enzymes as well as antioxidant indices during lung carcinogenesis in mice. Hum Exp Toxicol. 2015;34(6):620-627.

21. Narayanan NK, Nargi D, Randolph C, Narayanan BA. Liposome encapsulation of curcumin and resveratrol in combination reduces prostate cancer incidence in PTEN knockout mice. Int J Cancer. 2009; 125(1):1-8.

22. Garvin S, Ollinger K, Dabrosin C. Resveratrol induces apoptosis and inhibits angiogenesis in human breast cancer xenografts in vivo. Cancer Lett. 2006;231(1):113-122.

23. Seino M, Okada M, Shibuya K, et al. Differential contribution of ROS to resveratrol-induced cell death and loss of self-renewal capacity of ovarian cancer stem cells. Anticancer Res. 2015;35(1):85-96.

24. Kukreja A, Wadhwa N, Tiwari A. Therapeutic role of resveratrol and piceatannol in disease prevention. J Blood Disord Transfus. 2014;5(9): $1-6$.

25. Wei L, Liu T, Wang HH, et al. Hsp27 participates in the maintenance of breast cancer stem cells through regulation of epithelial-mesenchymal transition and nuclear factor-kB. Breast Cancer Res. 2011;13(5):R101.

26. Devipriya S, Ganapthy V, Shyamaladevi CS. Suppression of tumor growth and invasion in 9,10 dimethyl benz (a) anthracene induced mammary carcinoma by the plant bioflavonoid quercetin. Chem Biol Interact. 2006;162(2):106-113.

27. Miles SL, McFarland M, Niles RM. Molecular and physiological actions of quercetin: need for clinical trials to assess its benefits in human disease. Nutr Rev. 2014;72(11):720-734.

28. Kotecha R, Takami A, Espinoza JL. Dietary phytochemicals and cancer chemoprevention: a review of the clinical evidence. Oncotarget. 2016;7(32):52517-52529.

29. Baumrucker CR, Schanbacher F, Shang Y, Green MH. Lactoferrin interaction with retinoid signaling: cell growth and apoptosis in mammarycells. Domest Anim Endocrinol. 2006;30(4):289-303.

30. Bhat-Nakshatri P, Goswami CP, Badve S, Sledge GW, Nakshatri H. Identification of FDA-approved drugs targeting breast cancer stem cells along with biomarkers of sensitivity. Sci Rep. 2013;3:2530.

31. Zeng X, Cai D, Zeng Q, et al. Selective reduction in the expression of UGTs and SULTs, a novel mechanism by which piperine enhances the bioavailability of curcumin in rat. Biopharm Drug Dispos. 2017;38(1): 3-19.

32. Niedzwiecki A, Roomi MW, Kalinovsky T, Rath M. Anticancer efficacy of polyphenols and their combinations. Nutrients. 2016;8(9).pii:E552. doi: 10.3390/nu8090552.

33. Patil VM, Das S, Balasubramanian K. Quantum chemical and docking insights into bioavailability enhancement of curcumin by piperine in pepper. J Phys Chem A. 2016;120(20):3643-3653. 
34. Sak K. Chemotherapy and dietary phytochemical agents. Chemother Res Pract. 2012;2012:282570.

35. Pandit RS, Gaikwad SC, Agarkar GA, Gade AK, Rai M. Curcumin nanoparticles: physico-chemical fabrication and its in vitro efficacy against human pathogens. Biotech. 2015;5(6):991-997.

36. Yallapu MM, Jaggi M, Chauhan SC. Curcumin nanoformulations: a future nanomedicine for cancer. Drug Discov Today. 2012;17(1-2):71-80.

37. Wang S, Tan M, Zhong Z, Chen M, Wang Y. Nanotechnologies for curcumin: an ancient puzzler meets modern solutions. J Nanomater. 2011; 2011:1-8.

38. Bisht S, Feldmann G, Soni S, et al. Polymeric nanoparticle-encapsulated curcumin ("nanocurcumin"): a novel strategy for human cancer therapy. J Nanobiotechnology. 2007;5:3.

39. Panda AK, Bose S, Chakraborty S, Kajal K, Sa G. Intratumoral immune landscape: immunogenicity to tolerogenicity. Austin J Clin Immunol. 2015;2(1):1025.

40. World Health Organization. Global Health Estimates. Geneva: World Health Organization; 2013. Available from http://www.who.int/healthinfo/global_burden_disease/en/. Accessed July, 2016.

41. Thorn CF, Oshiro C, Marsh S, et al. Doxorubicin pathways: pharmacodynamics and adverse effects. Pharmacogenet Genomics. 2011; 21(7):440-446.

42. Razavi-Azarkhiavi K, Iranshahy M, Sahebkar A, Shirani K, Karimi G. The Protective Role of Phenolic Compounds Against Doxorubicininduced Cardiotoxicity: a Comprehensive Review. Nutr Cancer. 2016;68(6):892-917.

43. Chen WC, Lai YA, Lin YC, et al. Curcumin suppresses doxorubicininduced epithelial-mesenchymal transition via the inhibition of TGF- $\beta$ and PI3K/AKT signaling pathways in triple-negative breast cancer cells. J Agric Food Chem. 2013;61(48):11817-11824.

44. Meiyanto E, Putri DD, Susidarti RA, et al. Curcumin and its analogues (PGV-0 and PGV-1) enhance sensitivity of resistant MCF-7 cells to doxorubicin through inhibition of HER2 and NF-kB activation. Asian Pac J Cancer Prev. 2014;15(1):179-184.

45. Aggarwal BB, Shishodia S, Takada Y, et al. Curcumin suppresses the paclitaxel-induced nuclear factor-kappaB pathway in breast cancer cells and inhibits lung metastasis of human breast cancer in nude mice. Clin Cancer Res. 2005;11(20):7490-7498.

46. Kang HJ, Lee SH, Price JE, Kim LS. Curcumin suppresses the paclitaxel-induced nuclear factor-kappaB in breast cancer cells and potentiates the growth inhibitory effect of paclitaxel in a breast cancer nude mice model. Breast J. 2009;15(3):223-229.

47. Zhan Y, Chen Y, Liu R, Zhang H, Zhang Y. Potentiation of paclitaxel activity by curcumin in human breast cancer cell by modulating apoptosis and inhibiting EGFR signaling. Arch Pharm Res. 2014;37(8):1086-1095.

48. Gasperi MD, Cavazos D, deGraffenried L. Curcumin modulates breast cancer response in resistant breast cancer cells. Cancer Res. 2009; 69(24 Suppl):3098.

49. Serasanambati M, Chilakapati SR, Manikonda PK, Kanala JR, Chilakapati DR. Anticancer effects of brucine and gemcitabine combination in MCF-7 human breast cancer cells. Nat Prod Res. 2015; 29(5):484-490.

50. Zhou QM, Zhang H, Lu YY, Wang XF, Su SB. Curcumin reduced the side effects of mitomycin $\mathrm{C}$ by inhibiting GRP58-mediated DNA cross-linking in MCF-7 breast cancer xenografts. Cancer Sci. 2009; 100(11):2040-2045.

51. Zhou QM, Wang XF, Liu XJ, Zhang H, LuYY, Su SB. Curcumin enhanced antiproliferative effect of mitomycin $\mathrm{C}$ in human breast cancer MCF-7 cells in vitro and in vivo. Acta Pharmacol Sin. 2011;32(11):1402-1410.

52. Bayet-Robert M, Kwiatkowski F, Leheurteur M, et al. Phase I dose escalation trial of docetaxel plus curcumin in patients with advanced and metastatic breast cancer. Cancer Biol Ther. 2010;9(1):8-14.

53. World Health Organization. World Cancer Report 2014. Chapter 1.1. Geneva: World Health Organization; 2014.

54. Zhang N, Yin Y, Xu SJ, Chen WS. 5-Fluorouracil: mechanisms of resistance and reversal strategies. Molecules. 2008;13(8):1551-1569.
55. Shakibaei M, Buhrmann C, Kraehe P, Shayan P, Lueders C, Goel A. Curcumin chemosensitizes 5-fluorouracil resistant MMR-deficient human colon cancer cells in high density cultures. PLoS One. 2014;9(1):e85397.

56. Toden S, Okugawa Y, Jascur T, et al. Curcumin mediates chemosensitization to 5-fluorouracil through miRNA-induced suppression of epithelial-to-mesenchymal transition in chemoresistant colorectal cancer. Carcinogenesis. 2015;36(3):355-367.

57. Churchill M, Chadburn A, Bilinski RT, Bertagnolli MM. Inhibition of intestinal tumours by curcumin is associated with changes in the intestinal immune cell profile. J Surg Res. 2000;89(2):169-175.

58. Tunstall RG, Sharma RA, Perkins S, et al. Cyclooxygenase-2 expression and oxidative DNA adducts in murine intestinal adenomas: modification by dietary curcumin and implications for clinical trials. Eur J Cancer. 2006;42(3):415-421.

59. Anand P, Sundaram C, Jhurani S, Kunnumakkara AB, Aggarwal BB Curcumin and cancer: an "old-age" disease with an "age-old" solution. Cancer Lett. 2008;267(1):133-164.

60. Patel BB, Gupta D, Elliott AA, Sengupta V, Yu Y, Majumdar AP. Curcumin targets FOLFOX-surviving colon cancer cells via inhibition of EGFRs and IGF-1R. Anticancer Res. 2010;30(2):319-325.

61. Zhou X, You T, Wang WM, Zheng ZQ. [Curcumin combined FOLFOX induced cell apoptosis of gastric cancer and its mechanism research]. Zhongguo Zhong Xi Yi Jie He Za Zhi. 2013;33(6):810-813. Chinese [with English abstract]

62. Collett GP, Campbell FC. Curcumin induces c-jun N-terminal kinasedependent apoptosis in HCT116 human colon cancer cells. Carcinogenesis. 2004;25(11):2183-2189.

63. Aggarwal BB, Bhatt ID, Ichikawa $\mathrm{H}$, et al. Curcumin-biological and medicinal properties. In: Ravindran PN, Babu KN, Sivaraman K, editors. Turmeric: The Genus Curcuma. New York: CRC Press; 2007:297-368.

64. Xu G, Huang W, Zhang WM, et al. [Effects of combined use of curcumin and catechin on cyclooxygenase-2 mRNA expression in dimethylhydrazine-induced rat colon carcinogenesis]. Di Yi Jun Yi Da Xue Xue Bao. 2005;25(1):48-52. Chinese [with English abstract].

65. Zachariae H. Methotrexate side-effects. Br J Dermatol. 1990; 122(Suppl 36):127-133.

66. Hossain DM, Panda AK, Chakrabarty S, et al. MEK inhibition prevents tumour-shed transforming growth factor- $\beta$-induced T-regulatory cell augmentation in tumour milieu. Immunology. 2015;144(4):561-573.

67. Dhanasekaran S, Biswal BK, Sumantran VN, Verma RS. Augmented sensitivity to methotrexate by curcumin induced overexpression of folate receptor in KG-1 cells. Biochimie. 2013;95(8):1567-1573.

68. Misra R, Sahoo SK. Coformulation of doxorubicin and curcumin in poly(D,L-lactide-co-glycolide) nanoparticles suppresses the development of multidrug resistance in K562 cells. Mol Pharm. 2011; 8(3):852-866.

69. Rajasingh J, Raikwar HP, Muthian G, Johnson C, Bright JJ. Curcumin induces growth-arrest and apoptosis in association with the inhibition of constitutively active JAK-STAT pathway in T cell leukemia. Biochem Biophys Res Commun. 2006;340(2):359-368.

70. Kellner C, Zunino SJ. Nitric oxide is synthesized in acute leukemia cells after exposure to phenolic antioxidants and initially protects against mitochondrial membrane depolarization. Cancer Lett. 2004; 215(1):43-52.

71. Wu Y, Chen Y, Xu J, Lu L. Anticancer activities of curcumin on human Burkitt's lymphoma. Zhonghua Zhong Liu Za Zhi. 2002;24(4):348-352.

72. Gururajan M, Dasu T, Shahidain S, et al. Spleen tyrosine kinase (Syk), a novel target of curcumin, is required for B lymphoma growth. J Immunol. 2007;178(1):111-121.

73. Wang BL, Shen YM, Zhang QW, et al. Co-delivery of curcumin and doxorubicin by MPEG-PCL results in improved efficacy of systemically administered chemotherapy in mice with lung cancer. Int $J$ Nanomedicine. 2013;8:3521-3531.

74. Lee J, Im YH, Jung HH, et al. Curcumin inhibits interferon-alpha induced NF-kappaB and COX-2 in human A549 non-small cell lung cancer cells. Biochem Biophys Res Commun. 2005;334(2):313-318. 
75. Baharuddin P, Satar N, Fakiruddin KS, et al. Curcumin improves the efficacy of cisplatin by targeting cancer stem-like cells through p21 and cyclin D1-mediated tumour cell inhibition in non-small cell lung cancer cell lines. Oncol Rep. 2015;35(1):13-25.

76. Park DC, Yeo SG, Shin EY, Mok SC, Kim DH. Clusterin confers paclitaxel resistance in cervical cancer. Gynecol Oncol. 2006;103(3):996-1000.

77. Bava SV, Sreekanth CN, Thulasidasan AK, et al. Akt is upstream and MAPKs are downstream of NF- $\mathrm{KB}$ in paclitaxel-induced survival signaling events, which are down-regulated by curcumin contributing to their synergism. Int J Biochem Cell Biol. 2011;43(3):331-341.

78. Haslehurst AM, Koti M, Dharsee M, et al. EMT transcription factors snail and slug directly contribute to cisplatin resistance in ovarian cancer. BMC Cancer. 2012;12:91.

79. Deshpande SS, Maru GB. Effects of curcumin on the formation of benzo[a]pyrene derived DNA adducts in vitro. Cancer Lett. 1995; 96(1):71-80.

80. Rinaldi AL, Morse MA, Fields HW, et al. Curcumin activates the aryl hydrocarbon receptor yet significantly inhibits (-)-benzo(a)pyrene7R-trans-7,8-dihydrodiol bioactivation in oral squamous cell carcinoma cells and oral mucosa. Cancer Res. 2002;62(19):5451-5456.

81. Saha S, Adhikary A, Bhattacharya P, DAS T, Sa G. Death by design: where curcumin sensitizes drug-resistant tumours. Anticancer Res. 2012;32(7):2567-2584.

82. Dean M, FojoT, Bates S. Tumour stem cells and drug resistance. Nat Rev Cancer. 2005;5(4):275-284.

83. Nautiyal J, Kanwar SS, Yu Y, Majumdar AP. Combination of dasatinib and curcumin eliminates chemo-resistant colon cancer cells. $J \mathrm{Mol}$ Signal. 2011;6:7

84. Kakarala M, Brenner DE, Korkaya H, et al. Targeting breast stem cells with the cancer preventive compounds curcumin and piperine. Breast Cancer Res Treat. 2010;122:777-785.

85. Norris L, Karmokar A, Howells L, Steward WP, Gescher A, Brown K. The role of cancer stem cells in the anti-carcinogenicity of curcumin. Mol Nutr Food Res. 2013;57(9):1630-1637.

86. Ramasamy TS, Ayob AZ, Myint HH, Thiagarajah S, Amini F. Targeting colorectal cancer stem cells using curcumin and curcumin analogues: insights into the mechanism of the therapeutic efficacy. Cancer Cell Int. 2015;15:96.

87. Shehzad A, Wahid F, Lee YS. Curcumin in cancer chemoprevention: molecular targets, pharmacokinetics, bioavailability, and clinical trials. Arch Pharm (Weinheim). 2010;343(9):489-499.

88. Registry and Results Database of U.S. National Institutes of Health. Available from: www.clinicaltrials.gov. Accessed July, 2016.

89. Shao ZM, Shen ZZ, Liu CH, et al. Curcumin exerts multiple suppressive effects on human breast carcinoma cells. Int J Cancer. 2002; 98(2):234-240.

90. Schindler R, Mentlein R. Flavonoids and vitamin E reduce the release of the angiogenic peptide vascular endothelial growth factor from human tumor cells. J Nutr. 2006;136(6):1477-1482.

91. Di GH, Li HC, Shen ZZ, Shao ZM. [Analysis of antiproliferation of curcumin on human breast cancer cells and its mechanism]. Zhonghua Yi Xue Za Zhi. 2003;83(20):1764-1768. Chinese [with English abstract].

92. Bobrovnikova-Marjon EV, Marjon PL, Barbash O, Vander Jagt DL, Abcouwer SF. Expression of angiogenic factors vascular endothelial growth factor and interleukin-8/CXCL8 is highly responsive to ambient glutamine availability: role of nuclear factor-kappaB and activating protein-1. Cancer Res. 2004;64(14):4858-4869.

93. Yoon H, Liu RH. Effect of selected phytochemicals and apple extracts on NF-kappaB activation in human breast cancer MCF-7 cells. J Agric Food Chem. 2007;55(8):3167-3173.

94. Bachmeier BE, Mohrenz IV, Mirisola V, et al. Curcumin downregulates the inflammatory cytokines CXCL1 and -2 in breast cancer cells via NFkappaB. Carcinogenesis. 2008;29(4):779-789.

95. Hammamieh R, Sumaida D, Zhang X, Das R, Jett M. Control of the growth of human breast cancer cells in culture by manipulation of arachidonate metabolism. BMC Cancer. 2007;7:138.
96. Chen X, Hasuma T, Yano Y, et al. Inhibition of farnesyl protein transferase by monoterpene, curcumin derivatives and gallotannin. Anticancer Res. 1997;17(4A):2555-2564.

97. White EL, Ross LJ, Schmid SM, Kelloff GJ, Steele VE, Hill DL. Screening of potential cancer-preventing chemicals for inhibition of induction of ornithine decarboxylase in epithelial cells from rat trachea. Oncol Rep. 1998;5(3):717-722.

98. Ichiki K, Mitani N, Doki Y, Hara H, Misaki I, Saiki I. Regulation of activator protein-1 activity in the mediastinal lymph node metastasis of lung cancer. Clin Exp Metastasis. 2000;18(7):539-545.

99. Zhang J, Qi H, Wu C. [Research of anti-proliferation of curcumin on A549 human lung cancer cells and its mechanism]. Zhong Yao Cai. 2004;27(12):923-927. Chinese [with English abstract].

100. Rashmi R, Kumar S, Karunagaran D. Ectopic expression of Bcl$\mathrm{XL}$ or $\mathrm{Ku} 70$ protects human colon cancer cells (SW480) against curcumin-induced apoptosis while their down-regulation potentiates it. Carcinogenesis. 2004;25(10):1867-1877.

101. Rashmi R, Kumar S, Karunagaran D. Human colon cancer cells lacking Bax resist curcumin-induced apoptosis and Bax requirement is dispensable with ectopic expression of Smac or downregulation of Bcl-XL. Carcinogenesis. 2005;26(4):713-723.

102. Moussavi M, Assi K, Gómez-Muñoz A, Salh B. Curcumin mediates ceramide generation via the de novo pathway in colon cancer cells. Carcinogenesis. 2006;27(8):1636-1644.

103. Jeong WS, Kim IW, Hu R, Kong AN. Modulation of AP-1 by natural chemopreventive compounds in human colon HT-29 cancer cell line. Pharm Res. 2004;21(4):649-660.

104. Chen A, Xu J, Johnson AC. Curcumin inhibits human colon cancer cell growth by suppressing gene expression of epidermal growth factor receptor through reducing the activity of the transcription factor Egr-1. Oncogene. 2006;25(2):278-287.

105. Lev-Ari S, Maimon Y, Strier L, Kazanov D, Arber N. Down-regulation of prostaglandin E2 by curcumin is correlated with inhibition of cell growth and induction of apoptosis in human colon carcinoma cell lines. J Soc Integr Oncol. 2006;4(1):21-26.

106. Sokoloski JA, Shyam K, Sartorelli AC. Induction of the differentiation of HL-60 promyelocytic leukemia cells by curcumin in combination with low levels of vitamin D3. Oncol Res. 1997;9(1):31-39.

107. Pan MH, Chang WL, Lin-Shiau SY, Ho CT, Lin JK. Induction of apoptosis by garcinol and curcumin through cytochrome $\mathrm{c}$ release and activation of caspases in human leukemiaHL-60 cells. J Agric Food Chem. 2001;49(3):1464-1474.

108. Bielak-Mijewska A, Piwocka K, Magalska A, Sikora E. P-glycoprotein expression does not change the apoptotic pathway induced by curcumin in HL-60 cells. Cancer Chemother Pharmacol. 2004;53(2): $179-185$.

109. Mukherjee Nee Chakraborty S, Ghosh U, Bhattacharyya NP, Bhattacharya RK, Dey S, Roy M. Curcumin induced apoptosis in human leukemia cell HL-60 is associated with inhibition of telomerase activity. Mol Cell Biochem. 2007;297(1-2):31-39.

110. Pae HO, Jeong SO, Jeong GS, et al. Curcumin induces pro-apoptotic endoplasmic reticulum stress in human leukemia HL-60 cells. Biochem Biophys Res Commun. 2007;353(4):1040-1045.

111. Ghosh AK, Kay NE, Secreto CR, Shanafelt TD. Curcumin inhibits prosurvival pathways in chronic lymphocytic leukemia B cells and may overcome their stromal protection in combination with EGCG. Clin Cancer Res. 2009;15(4):1250-1258.

112. Chen $\mathrm{Y}, \mathrm{Wu} \mathrm{Y}, \mathrm{He} \mathrm{J}, \mathrm{Chen} \mathrm{W}$. The experimental and clinical study on the effect of curcumin on cell cycle proteins and regulating proteins of apoptosis in acute myelogenous leukemia. J Huazhong Univ Sci Technolog Med Sci. 2002;22(4):295-298.

113. Woo JH, Kim YH, Choi YJ, et al. Molecular mechanisms of curcumininduced cytotoxicity: induction of apoptosis through generation of reactive oxygen species, down-regulation of Bcl-XL and IAP, the release of cytochrome $\mathrm{c}$ and inhibition of Akt. Carcinogenesis. 2003;24(7):1199-1208. 
114. Shankar S, Chen Q, Sarva K, Siddiqui I, Srivastava RK. Curcumin enhances the apoptosis-inducing potential of TRAIL in prostate cancer cells: molecular mechanisms of apoptosis, migration and angiogenesis. J Mol Signal. 2007;2:10.

115. Shi P, Chen WW, Hu XY, et al. [Up-regulates the expression of maspin gene in prostate cancer cell line LNCaP]. Yaо Хие Хие Вао. 2006;41(12):1152-1156. Chinese [with English abstract].

116. Chaudhary LR, Hruska KA. Inhibition of cell survival signal protein kinase B/Akt by curcumin in human prostate cancer cells. $J$ Cell Biochem. 2003;89(1):1-5.

117. Deeb D, Jiang H, Gao X, et al. Curcumin [1,7-bis(4-hydroxy-3methoxyphenyl)-1-6-heptadine-3,5-dione; C21H20O6] sensitizes human prostate cancer cells to tumor necrosis factor-related apoptosisinducing ligand/Apo2L-induced apoptosis by suppressing nuclear factor-kappaB via inhibition of the prosurvival Akt signaling pathway. J Pharmacol Exp Ther. 2007;321(2):616-625.

118. Kim JH, Xu C, Keum YS, Reddy B, Conney A, Kong AN. Inhibition of EGFR signaling in human prostate cancer PC-3 cells by combination treatment with beta-phenylethyl isothiocyanate and curcumin. Carcinogenesis. 2006;27(3):475-482.

119. Wei SC, Lin YS, Tsao PN, Wu-Tsai JJ, Wu CH, Wong JM. Comparison of the anti-proliferation and apoptosis induction activities of sulindac, celecoxib, curcumin, and nifedipine in mismatch repair-deficient cell lines. J Formos Med Assoc. 2004;103(8):599-606.

120. Reddy S, Rishi AK, Xu H, Levi E, Sarkar FH, Majumdar AP. Mechanisms of curcumin- and EGF-receptor related protein (ERRP)dependent growth inhibition of colon cancer cells. Nutr Cancer. 2006;55(2):185-194.

121. Roy M, Chakraborty S, Siddiqi M, Bhattacharya RK. Induction of apoptosis in tumor cells by natural phenolic compounds. Asian Pac J Cancer Prev. 2002;3(1):61-67.

122. Divya CS, Pillai MR. Antitumor action of curcumin in human papillomavirus associated cells involves downregulation of viral oncogenes, prevention of NFkB and AP-1 translocation, and modulation of apoptosis. Mol Carcinog. 2006;45(5):320-332.

123. Yu Z, Shah DM. Curcumin down-regulates Ets-1 and Bcl-2 expression in human endometrial carcinoma HEC-1 A cells. Gynecol Oncol. 2007;106(3):541-548.

124. Khafif A, Hurst R, Kyker K, Fliss DM, Gil Z, Medina JE. Curcumin: a new radio-sensitizer of squamous cell carcinoma cells. Otolaryngol Head Neck Surg. 2005;132(2):317-321.
125. Atsumi T, Murakami Y, Shibuya K, Tonosaki K, Fujisawa S. Induction of cytotoxicity and apoptosis and inhibition of cyclooxygenase-2 gene expression, by curcumin and its analog, alpha-diisoeugenol. Anticancer Res. 2005;25(6B):4029-4036.

126. Thompson KH, Böhmerle K, Polishchuk E, et al. Complementary inhibition of synoviocyte, smooth muscle cell or mouse lymphoma cell proliferation by a vanadyl curcumin complex compared to curcumin alone. J Inorg Biochem. 2004;98(12):2063-2070.

127. Skommer J, Wlodkowic D, Pelkonen J. Cellular foundation of curcumin-induced apoptosis in follicular lymphoma cell lines. Exp Hematol. 2006;34(4):463-474.

128. Uddin S, Hussain AR, Manogaran PS, et al. Curcumin suppresses growth and induces apoptosis in primary effusion lymphoma. Oncogene. 2005;24(47):7022-7030.

129. Choudhuri T, Pal S, Agwarwal ML, Das T, Sa G. Curcumin induces apoptosis in human breast cancer cells through p53-dependent Bax induction. FEBS Lett. 2002;512(1-3):334-340.

130. Mackenzie GG, Queisser N, Wolfson ML, Fraga CG, Adamo AM, Oteiza PI. Curcumin induces cell-arrest and apoptosis in association with the inhibition of constitutively active NF- $\kappa$ B and STAT3 pathways in Hodgkin's lymphoma cells. Int J Cancer. 2008;123(1):56-65.

131. Shanker A, Brooks AD, Tristan CA, et al. Treating metastatic solid tumors with bortezomib and a tumor necrosis factor-related apoptosis-inducing ligand receptor agonist antibody. J Natl Cancer Inst 2008;100(9):649-662.

132. Hussain AR, Ahmed M, Al-Jomah NA, et al. Curcumin suppresses constitutive activation of nuclear factor-kappa B and requires functional Bax to induce apoptosis in Burkitt's lymphoma cell lines. Mol Cancer Ther. 2008;7(10):3318-3329.

133. Singh M, Singh N. Molecular mechanism of curcumin induced cytotoxicity in human cervical carcinoma cells. Mol Cell Biochem. 2009;325(1-2):107-119.

134. Lin SS, Huang HP, Yang JS, et al. DNA damage and endoplasmic reticulum stress mediated curcumin-induced cell cycle arrest and apoptosis in human lung carcinoma A-549 cells through the activation caspases cascade- and mitochondrial dependent pathway. Cancer Lett. 2008;272(1):77-90.
Journal of Experimental Pharmacology

\section{Publish your work in this journal}

The Journal of Experimental Pharmacology is an international, peerreviewed, open access journal publishing original research, reports, reviews and commentaries on all areas of laboratory and experimental pharmacology. The manuscript management system is completely online and includes a very quick and fair peer-review system.
Dovepress

Visit http://www.dovepress.com/testimonials.php to read real quotes from published authors. 